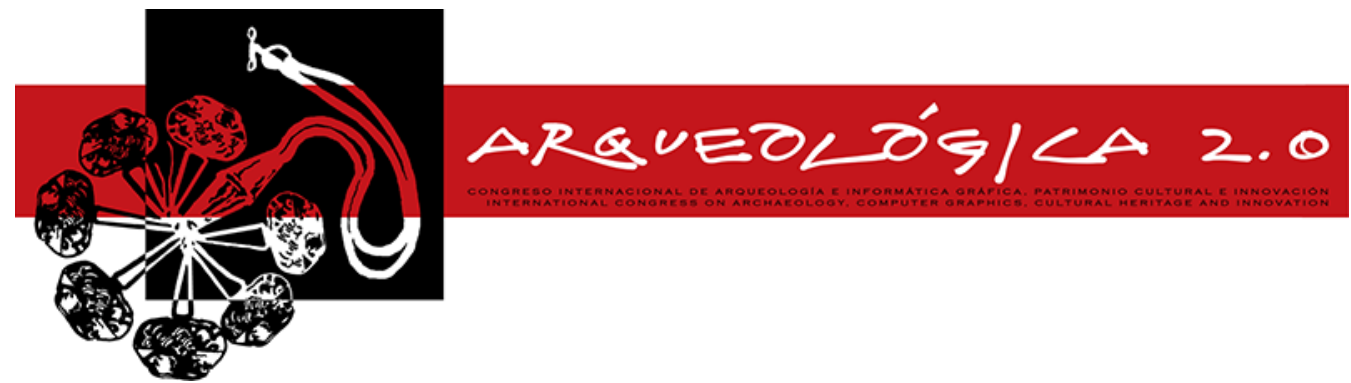

Proceedings of the $8^{\text {th }}$ International Congress

on Archaeology,

Computer Graphics,

Cultural Heritage and Innovation

'ARQUEOLÓGICA 2.0'

in Valencia (Spain),

Sept. 5-7, 2016

DOI: http://dx.doi.org/10.4995/arqueologica8.2016.4200

Received: $17 / 04 / 2016$

Accepted: 01/06/2016

\title{
BIG DATA IN LANDSCAPE ARCHAEOLOGICAL PROSPECTION
}

\author{
"BIG DATA" EN PROSPECCIÓN ARQUEOLÓGICA DEL PAISAJE \\ Juan Torrejón", Mario Wallner, Immo Trinks, Matthias Kucera, Nika Luznik, Klaus Löcker, \\ Wolfgang Neubauer \\ Ludwig Boltzmann Institute for Archaeological Prospection and Virtual Archaeology, Hohe Warte 38, 1190 Vienna, Austria. \\ Juan.Torrejon-Valdelomar@archpro.lbg.ac.at
}

\begin{abstract}
:
While traditionally archaeological research has mainly been focused on individual cultural heritage monuments or distinct archaeological sites, the Austrian based Ludwig Boltzmann Institute for Archaeological Prospection and Virtual Archaeology goes beyond the limitations of discrete sites in order to understand their archaeological context. This is achieved by investigating the space in-between the sites, studying entire archaeological landscapes from the level of individual postholes to the mapping of numerous square kilometres. This large-scale, high-resolution, multi-method prospection approach leads to enormous digital datasets counting many terabytes of data that until recently were technically not manageable. Novel programs and methods of data management had to be developed for data acquisition, processing and archaeological interpretation, in order to permit the extraction of the desired information from the very big amount of data. The analysis of the generated datasets is conducted with the help of semi-automatic algorithms within complex three-, or even four-dimensional geographical information systems. The outcome of landscape archaeological prospection surveys is visually communicated to the scientific community as well as to the general public and stakeholders. In many cases, a visualization of the scientific result and archaeological interpretations can be a powerful and suitable tool to illustrate and communicate even complex contexts to a wide audience. This paper briefly presents the great potential offered by a combination of large-scale non-invasive archaeological prospection methods and standardized workflows for the integration of big data, its interpretation and visualization. The proposed approach provides a context for buried archaeology across entire archaeological landscapes, changing our understanding of known monuments. We address the overcome and remaining challenges with the help of examples taken from outstanding landscape archaeological prospection case studies.
\end{abstract}

Key words: big data, large-scale, high-resolution, non-invasive, archaeological prospection, near-surface geophysics, virtual archaeology, data interpretation, landscape archaeology, preservation, dissemination

\section{Resumen:}

Aunque tradicionalmente la investigación arqueológica ha estado fundamentalmente centrada en monumentos y yacimientos arqueológicos de forma individual, el Ludwig Boltzmann Institute for Archaeological Prospection and Virtual Archaeology (Austria) va más allá de los límites de yacimientos particulares con el objetivo de entender su contexto arqueológico. Esto es conseguido mediante la investigación del espacio entre yacimientos y estudiando paisajes arqueológicos completos yendo desde un hoyo de poste hasta el mapeado de varios kilómetros cuadrados. El enfoque de prospección multi-metodológico a gran escala y de alta resolución conduce hacia un enorme conjunto de datos digital que incluye varios Terabytes de información los cuales no habían podido ser manipulados hasta hace poco debido a limitaciones tecnológicas. Por consiguiente, nuevos programas y métodos de gestión de datos han sido diseñados para la adquisición y procesado de datos así como interpretación arqueológica para así permitir la extracción de la información deseada desde estos enormes bancos de datos. El análisis de estos conjuntos de datos generados es llevado a cabo a través de análisis de sistemas de información geográfica tridimensionales e incluso cuatridimensionales. El resultado de la prospección de paisajes arqueológicos es transferido de forma visual a la comunididad científica así como al gran público e interesados en la materia. En muchos casos una visualización de los resultados científicos e interpretaciones arqueológicas puede ser una herramienta más poderosa y adecuada para ilustrar y comunicar contextos arqueológicos complejos a un público mayor. Este artículo presenta de forma breve el gran potencial ofrecido por la combinación de métodos de prospección arqueológica de gran resolución a gran escala y unos flujos de trabajo estandarizados para integración, interpretación y visualización de datos. La estrategía propuesta proporciona un contexto para restos arqueológicos enmarcados en paisajes arqueológicos que viene a cambiar nuestra

*Corresponding Author: Juan Torrejón, Juan.Torrejon-Valdelomar@archpro.lbg.ac.at 
forma de entender monumentos ya conocidos. Pretendemos también superar los desafios que quedan con la ayuda de ejemplos sacados de excepcionales paisajes arqueológicos que son nuestros estudios de caso a prospectar.

Palabras clave: big data, gran escala, alta resolución, métodos no-invasivos, prospección arqueológica, métodos geofísicos en superficie, arqueología virtual, interpretación de datos, arqueología del paisaje, preservación, difusión.

\section{Introduction}

Archaeology, as a discipline of humanities, is defined by its subject of study, which always has been the scholarly investigation of remains, activities and culture of past people and societies. Scientifically, archaeology has also been defined by the methods and techniques that are used. Over the past decades, archaeological science increasingly gained importance due to the introduction of various analytical tools and techniques rooting in, or derived from the field of natural sciences. Today, a large number of advanced scientific methods can be applied to study and solve archaeological problems, reflecting the complexity of the investigated multi-layered systems and the past interactions of people and societies with their natural environment, which they were part of and dependent on. Given the argument that every archaeological context, site or landscape, is unique, the question arises how to choose among the different available methods and how to apply them in a welldefined way and efficient manner in order to protect this steadily decreasing cultural resource.

Archaeologists are usually prone to rather describe than to interpret the collected data. This might be due to the very specific character of archaeology as a discipline located in-between humanities and natural sciences, and the resulting tension. Therefore, some archaeologists may tend more to describe situations with respect to objectivity (e.g. by documenting stratigraphic units during an archaeological excavation and by collecting and describing material samples) instead of providing an archaeological interpretation of the data. Archaeological interpretations, especially when derived from data gained with different methods, may be more likely to be exposed to criticism, and therefore often seem to be avoided. However, new knowledge on the development and history of archaeological landscapes and the embedded sites can only be gained when an archaeological interpretation of all the available data is conducted and provided.

In order to counteract criticism of subjective constructions and to achieve greatest possible degree of objectivity concerning the resulting archaeological interpretations, the reproducibility of the interpretation has to be ensured by application of well-defined methods. In this way we could get closer to answering the question of how observed archaeological remains might have looked at specific moments in time, reflecting the entire circle of their production, use and decay. For this purpose the archaeological interpretation process has to follow strict rules. A possible interpretation could be presented among other plausible versions, and their probabilities should be discussed.

In order to investigate a specific archaeological site, the knowledge about the archaeological landscape in which it is embedded is crucial. As an example, the functionality of a settlement depends on the surrounding fields, communication pathways, minor rural buildings, military constructions, etc. A traditional archaeological investigation by invasive excavation of a site and its surrounding landscape would imply its destruction in an unrealistically expensive and time-consuming process, which neither is possible nor desirable.

If the surrounding area is not investigated, most of the context of an archaeological site would be missing. Without this information past societies could hardly be described in a thoroughly manner. Being aware, that a complete invasive study of archaeological remains at the scale of landscapes is not possible, the aim should be to apply methods that have the potential to close this gap, even if only partly. Modern archaeology should be understood as a multi-methodological discipline, which results in a large amount of data and information that has to be interlinked and interpreted within a given archaeological setting.

Non-invasive, large-scale, high-resolution archaeological prospection using a combination of remote sensing and near-surface geophysical survey methods offers the potential to permit the detailed investigation of archaeological sites and their surrounding landscapes with blanket coverage in a cost- and time-efficient manner without damaging the cultural heritage.

Aside of the aspect of archaeological research, another important reason for the use of innovative large-scale non-invasive prospection methods is related to the preservation of endangered cultural heritage, which primarily requires knowledge on the distribution and extent of the archaeological remains hidden in the subsurface.

While landscape archaeological prospection is well suited to discover and document new archaeological evidence and sites, it can also be applied to the investigation of already known monuments.

An important issue that is encountered when dealing with landscape archaeological investigations using a multi-methodological large-scale prospection approach are the enormous amount of data that are generated, corresponding data management issues, data integration, data interpretation and the dissemination of the results. The huge datasets have to be handled and interpreted following well-defined workflows and procedures. In this paper we address these issues relating to Big Data in landscape archaeological prospection, drawing on case study examples of the Austrian Ludwig Boltzmann Institute for Archaeological Prospection and Virtual Archaeology (LBI ArchPro).

The data dealt with in this context and presented here truly constitutes Big Data since the size of the data sets have been beyond the ability of commonly used software tools and special algorithm had to be developed to permit the processing, analysis and interpretation of the data. The followed approach to dealing with the Big Data involved the development and application of automatic and semi-automatic data segmentation and classification 
algorithms as well as the development of new data fusion tools.

\section{Methodology}

While large-scale archaeological excavation and trenching still is commonly used within rescue and exploration archaeology, since few years increasingly non-invasive means for the exploration, documentation and investigation of buried heritage are entering the commercial sector as well as archaeological research. The common knowledge about the potential of archaeological prospection methods is continuously increasing.

Regarding remote sensing methods, apart from aerial photography (both oblique- and ortho-photos), airborne laser scanning and hyperspectral scanning are promising methods for the digital detection, mapping and documentation of buried archaeological sites and remaining traces in the topography (Doneus 2013, Neubauer 2012b, Neubauer 2014). The most appropriate geophysical measurement methods for large-scale high-resolution archaeological prospection are magnetometer measurements and groundpenetrating radar surveys. While some of these methods, such as magnetometry and aerial photography, look back at several decades of development and use, others have only recently been introduced into the archaeological toolbox.

\subsection{Remote sensing}

Remote sensing methods used by the LBI ArchPro for large-scale archaeological prospection are aerial photography, airborne laser scanning and airborne hyperspectral scanning.

\subsubsection{Aerial photography}

Aerial archaeology is a very cost-effective method for site discovery with the potential to provide detailed maps of archaeological structures, showing up on the surface as so called "visibility marks", i.e. slight topographic variations visible as shadow-marks, soil-marks due to varying chemical and physical properties affecting soil colour on the surface, and crop-marks due to variable growth of the vegetation or frost-marks due to varying thermal properties. Georeferenced and rectified vertical and oblique aerial photos from reconnaissance flights are used to derive the archaeological interpretation of detected structures or features. In that way, repetitive observations can be combined into an extensive overall view of an archaeological region, which will be used as basic information for further prospecting, excavations, protection measures, and spatial archaeology.

\subsubsection{Airborne imaging spectroscopy (AIS)}

Aerial archaeologists conventionally focus their interest on the visible and near-infrared (NIR) radiation. Using analogue film or digital sensors, these visible as well as the NIR bands of the spectrum can be recorded within up to three bands with bandwidths of roughly $100 \mathrm{~nm}$. However, each plant is showing a characteristic signature within the entire spectrum depending on its type, environmental conditions and stress due to the archaeological structure underneath. This characteristic spectral "fingerprint" can only be visualized crudely by the three bands of conventional imaging. Therefore, current standard photographic techniques do often not allow for the detection of crop-marks if the contrast exhibited to the surrounding matrix is too low within the range of the visible or NIR spectrum. Using airborne imaging spectroscopy (AIS - also referred to as airborne hyperspectral scanning) devices, there is a high potential to overcome the limitations of conventional aerial photography and significantly enhance the detection of archaeological structures even under less favourable conditions.

Commercial AIS systems have become available only during the past decade. They measure upwelling electromagnetic radiation (reflected and/or emitted) in a multitude of small spectral bands of only a few nanometres width. Since all of these bands can be analysed individually, a detailed investigation of those parts of the plant's spectral signature that are most significant for signs of stress, is possible.

In this way, imaging spectroscopy data does have the potential to overcome the limitations of conventional aerial photography, strengthening the understanding of the particular phenomena aerial archaeologists try to visualize, and significantly enhancing the possibilities for the detection of archaeological structures even under less favourable conditions. However, AIS and its archaeological application is still a new technology requiring further systematic investigation.

\subsubsection{Laser scanning (airborne \& terrestrial)}

Over the past few years, airborne (ALS) and terrestrial laser scanning (TLS) has turned out to be a potential tool for recognition and measurement of archaeological features that survived in the topography in open and wooded areas. ALS results in a precise model of the surface, however, there is no way to detect buried features or sites that have not left traces in the relief using this method. While archaeological applications of ALS are increasing, they are still often restricted to nonforested areas. Due to its ability to measure the ground under a vegetation canopy, ALS has a major impact on the archaeological reconnaissance of forested areas. To extend aerial archaeology with state-of-the-art ALS and to develop and advance the application of ALS for archaeological prospection is a promising field of research.

Full-waveform (FWF) LS systems have considerable advantages for the generation of digital terrain models (DTM) in vegetated areas, as the FWF-parameters might improve the classification of LS data into terrain and offterrain points, resulting in improved DTM quality and a greater potential for the subsequent archaeological interpretation.

LS data provides the basis for accurate post-processing and spatial analysis of prospection data in landscape archaeology, as well as for the monitoring of cultural heritage sites.

\subsection{Near-surface geophysical prospection}

Traditionally, near-surface geophysical prospection methods have been used manually, permitting only slow measurement progress. Using multichannel motorized 
magnetometer and ground-penetrating radar (GPR) arrays and exact satellite positioning systems is has become possible to map large areas quickly and with very high resolution, resulting in data of unprecedented quality and quantity.

\subsubsection{Magnetic prospection}

Magnetometry is most suitable to map all kinds of archaeological structures causing anomalies in the Earth's magnetic field, such as pits, trenches, postholes, walls, fire places and kilns, across large, open, unobstructed areas. Magnetometer surveys result in one single data value per surface point without direct information about the depth of detected buried structures.

The most important issues regarding professional archaeological prospection are speed, sensitivity and spatial resolution. The coverage of considerably larger areas and increased sample densities at constant expenditure of time in the field are today possible by high inherent sample rates of the used instruments, by higher survey speed through the use of motorized multichannel survey systems and advanced data positioning and navigation solutions. The use of motorized measurement devices for archaeological prospection implicates several technological and methodological challenges.

State-of-the-art fluxgate gradiometer (FG) and very sensitive Caesium (CS) magnetometer systems are operated on purpose-built non-magnetic carts towed by motorized All-Terrain-Vehicles (ATV) or Quad bikes. The ATVs carry the power supply, the data logging unit and advanced positioning and navigation systems. Multiple sensor arrangements with up to $10 \mathrm{FG}$ probes mounted with $25 \mathrm{~cm}$ cross-line spacing on the trailers, as well as access to two dozen CS sensors permits the setup of several magnetometer arrays for efficient large-scale magnetic surveys.

\subsubsection{Ground-penetrating radar surveys}

GPR surveys provide under suitable ground conditions detailed three dimensional information about approximate depth, shape and location of archaeological structures at a high spatial resolution. They can be used to detect for example stone structures (walls or postholes containing stones), interfaces caused by pits and trenches, cavities and differences in soil humidity.

Until recently, GPR surveys have been limited to relatively small-scale applications due to the lack of availability of multichannel antenna arrays. The common use of single antenna systems with often inappropriately large profile spacing results mostly in low-resolution data images. New multichannel GPR arrays, which have been developed over the past years, appear on the market and are being tested for archaeological prospection. They permit considerably increased spatial coverage with simultaneously greatly improved sample spacing, resulting in images of the subsurface with unprecedented resolution and structural clarity. Largescale GPR prospection is conducted using various multichannel GPR arrays of fixed frequency, such as the 16 channel $400 \mathrm{MHz}$ MALÅ Imaging Radar Array (MIRA) with $8 \mathrm{~cm}$ channel spacing.

\subsection{Data processing}

Appropriate data recording software as well as efficient navigation solutions are required for high-speed largescale archaeological prospection gathering really Big Data. The huge amount of data generated by the remote sensing and geophysical prospection measurements demands appropriate data processing and visualization tools. Data acquired with motorized survey systems requires correct interpolation algorithms. New filtering tools for the removal of disturbing noise and for the generation of optimised final data images needed to be developed. The effect of the surface conditions and topography has to be taken into account.

While commercially available software for the processing of near-surface geophysical prospection data are severely limited in amount and size of data that can be handled, our specifically developed tools for the handling of the Big Data sets acquired are now only limited by the physical specs of the computers used.

Different data sets collected at various scales need to be merged and integrated into a GIS geo-database prior to archaeological interpretation. The novel GIS extension ArchaeoAnalyst is a toolbox for Big Data visualisation and exploration, permitting improved spatio-temporal data analysis in 3D. It was specially designed to interact as the central steering-wheel for the control of the huge archaeological information projects. The researcher gains the opportunity to adapt the processed and visualized data to a specific research question, and therefore is able to efficiently extract detailed 4D information from the massive digital data volumes.

Within the huge datasets also the data management is an important task, since many Terabytes of raw- and processed data have to be dealt with and countless of resulting data visualization images are generated.

\subsection{Integrated archaeological interpretation}

The proposed approach produces new complex datasets of archaeological landscapes. These demand adequate data management and an integrated archaeological interpretation. Therefore, novel concepts of dynamic analysis including temporal relations and attributes have been developed. The main challenge has been the transformation of the acquired and processed complex physical prospection data into interpretative archaeological information that is accurate, readable and ready to use for our researchers and the scientific community.

Based on these requirements, an integrative platform is developed, permitting close collaboration on data management and integrated archaeological interpretation. The main platform is a GIS-based archaeological information system (AIS), extended by appropriate tools for dynamic visualization, spatial analysis for integrated archaeological interpretation, data archiving, data retrieval, and long term maintenance.

While data analysis and interpretation in GIS environments have become commonplace in professional practise, the development and use of intelligent feature extraction and semi-automatic interpretation algorithms and advanced visualization tools still are in their infancy. 
It is reasonable that an archaeological interpretation shouldn't be based on the analysis of data obtained with a single method alone. Only by integrating all available data into one archaeological interpretation it is possible to gain the most complete information on the buried archaeology, compensating the weaknesses of the different methods.

Once all the different georeferenced prospection data are interpreted within the AIS, a general overview on the archaeological structures is compiled from the different datasets. Through this integration of different sources of archaeological information it is possible to investigate huge areas in great detail, and to understand the temporal development of an archaeological landscape in its regional and historical context. The bigger and seamless the surveyed area is, the higher is the chance to find overlapping or intersecting structures that hold the key to address these temporal questions.

\section{3D visualization of the interpretation(s)}

The idea behind the $3 \mathrm{D}$ visualization process, as the final step of the proposed approach on how to deal with big data in landscape archaeological prospection projects, is in its essence rather straightforward. The generated virtual models follow the guidelines established in the London Charter (2009) and Principles of Seville (2011). Special attention is given to scientific transparency and traceability.

Handling big data sets is still a challenge for the generation of detailed 3D visualizations due to the inherent computational demands of detailed highpolygonal models. Questions concerning model reductions and simplifications need to be addressed and it may be necessary to explore novel ways to present the large amount of data in 3D (atoms instead of polygons).

Special care has to be given to the correct alignment of the data derived from multiple sources. To the extent possible, the data is georeferenced and aligned automatically.

As a base for any placement of anthropogenic features a scientifically evaluated model of historical landscape is created first. It is very important that all the traces of recent human activities are erased from the DTM of the area and appropriate different, natural features, such as rivers or seashore, are recreated. In order to do so, historical maps may be of use.

Following best scientific knowledge, anthropogenic structures are placed in the model, starting with infrastructural features, such as roads, up to reconstructed architecture and entire settlements. The reconstruction of architectural features starts slowly with the definition of their volumes, and it is continuously refined, where appropriate to high levels of detail. Most of the areas are not shown in detail and the mayor parts of the models remain rather coarse; there details are merely represented through the applied texture.

At each site there exist better preserved parts, suited for a closer representation and detailed modelling. The sources for such detailed visualizations can either be directly found as analogies in archaeological excavations, historical sources, and still standing architectural remains.

Additionally important are architectural and structural models based on experimental archaeology. These test archaeological hypotheses by employing methods, techniques, analyses and approaches relying on archaeological source material (Ascher, 1961).

When comparing datasets from archaeological excavations and geophysical prospection surveys, mismatches may be observed. In any case, it is important to make clear that an archaeological excavation is neither able to verify nor to falsify the results of a geophysical prospection survey; it is only able to question the quality of the archaeological interpretation derived from the geophysical prospection data (Löcker et al., 2015).

An innovative approach in this field is to create $3 D$ models from features existing in reality by laser scanning and/or image based modelling techniques. These models can then directly be imported into the visualization scene. Through this process we are able to capture reality and to transfer it into our digital environment, consequently enhancing the virtual scene.

Our approach to the scene enrichment varies from bare architectural models in a land- or townscape to fully naturalistic environments with vegetation, animals, people and small everyday objects. In order to better understand the development of the landscape through time, multiple phases are thoroughly modelled. These models provide the possibility to explore and gain further insights into the interaction between the past landscape and its inhabitants.

\section{Application examples}

The 'Stonehenge Hidden Landscape Project', the 'ArchPro Carnuntum' project and the 'Kreuttal' case study represent application examples of the proposed approach. With over 12 square kilometres of prospected area surrounding the main Stonehenge monument, an entirely new picture of the past landscape and its use throughout times emerged. Numerous buried monuments and countless features of archaeological interest have been discovered, mapped, interpreted and added to the archaeological record (Figs. 1 and 2).

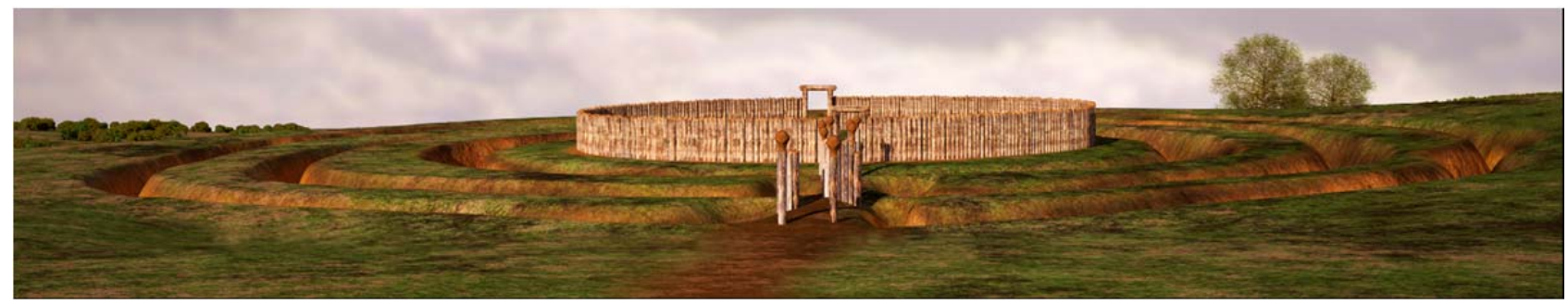

Figure 1: 3D visualisation of the landscape in Kreuttal, Austria. 


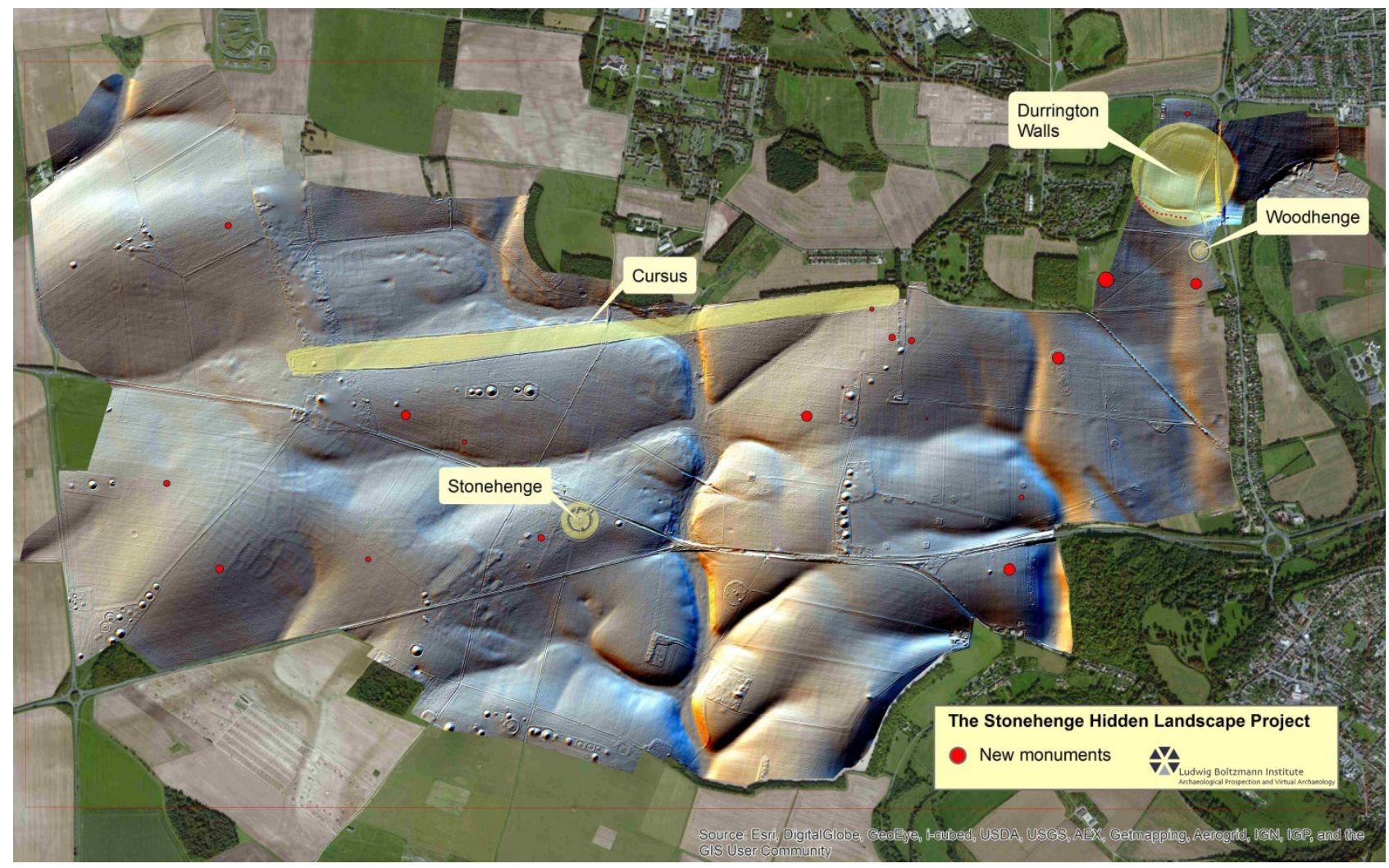

Figure 2: The Stonehenge Hidden Landscape Project Area.

The Roman town of Carnuntum in Austria and the associated Legionary camp and military installation have been explored using the described landscape archaeological methodology, covering eight square kilometres of magnetometry and almost three square kilometres of ultra-high-definition GPR measurements, embedded into an ALS-derived DTM (Fig. 3). The acquisition, processing and interpretation of this truly Big Data set has been accomplished within 36 months, which only has been possible due to the here presented best practice (Neubauer et al. 2012a, Trinks et al. 2012, Neubauer 2011, Doneus and Briese 2011).

The case study 'Kreuttal' covers an area of 54 square kilometres, providing a variety of different data sets, such as large-scale magnetometry, hyperspectral scanning data, ALS data, historical aerial photographs, historical maps, archaeological field walking data, and data from archaeological excavations. Its depth in time ranges from the early Neolithic to modern times. It provides an ideal example to study the perceived emptiness in-between and to fill the gaps in our understanding of this archaeological landscape.

\section{Dissemination}

Dissemination of the generated findings is the last and equally important step, where the gathered knowledge is shared with the community, being it scientific and/or the general public. There are many ways to do so and the dissemination techniques and visualisation format varies according to the target audience.

One of the last successful dissemination projects presenting the Big Data acquired at Stonehenge was the
Stonehenge exhibition realized at MAMUZ museum in Mistelbach, Austria.

Here, the entire exhibition is dedicated to reveal the significance of the vast prehistoric landscape of the wider Stonehenge area. It is linked to results from the Kreuttal case study concerning Middle Neolithic monumental architecture that today only is visible in the prospection data.

In doing so, many different techniques have been utilized, ranging from still images, descriptive texts, animations showing the change of the landscape throughout time, highlighting several special areas, an interactive 3D game placing the visitor in the role of the archaeologist exploring the landscape, as well as a 3D printed scale-model and life-sized reconstruction of parts of the monument. In doing so many aspects and facets of the landscape can be displayed for an enhanced offsite visitor experience.

While exhibitions like this are of value for the dissemination of novel research to the wider public, even the research community benefits from the possibilities to immersively experience Big Data and to discuss monuments in their wider landscape setting and archaeological context.

\section{Conclusions}

For the interpretation of a specific archaeological context, a well-defined workflow of applied techniques and methods concerning the acquisition, managing, processing and analysis of Big Data is necessary. All presented procedures and workflows have to be standardized in order to guarantee reproducibility. Specific training in the interdisciplinary analysis of 
landscape archaeological prospection data is necessary. As the environment for the subsequent spatio-temporal analysis of archaeological datasets, a GIS-based AIS consisting of recently developed tools has proven to be the most efficient modus operandi. Together with predefined geodatabases the huge data volumes become manageable. The implementation of time into AIS following the fundamental rules of superposition, resulting in a stratigraphic sequence, enables us to examine the spatio-temporal correlations and introduces time into the GIS.

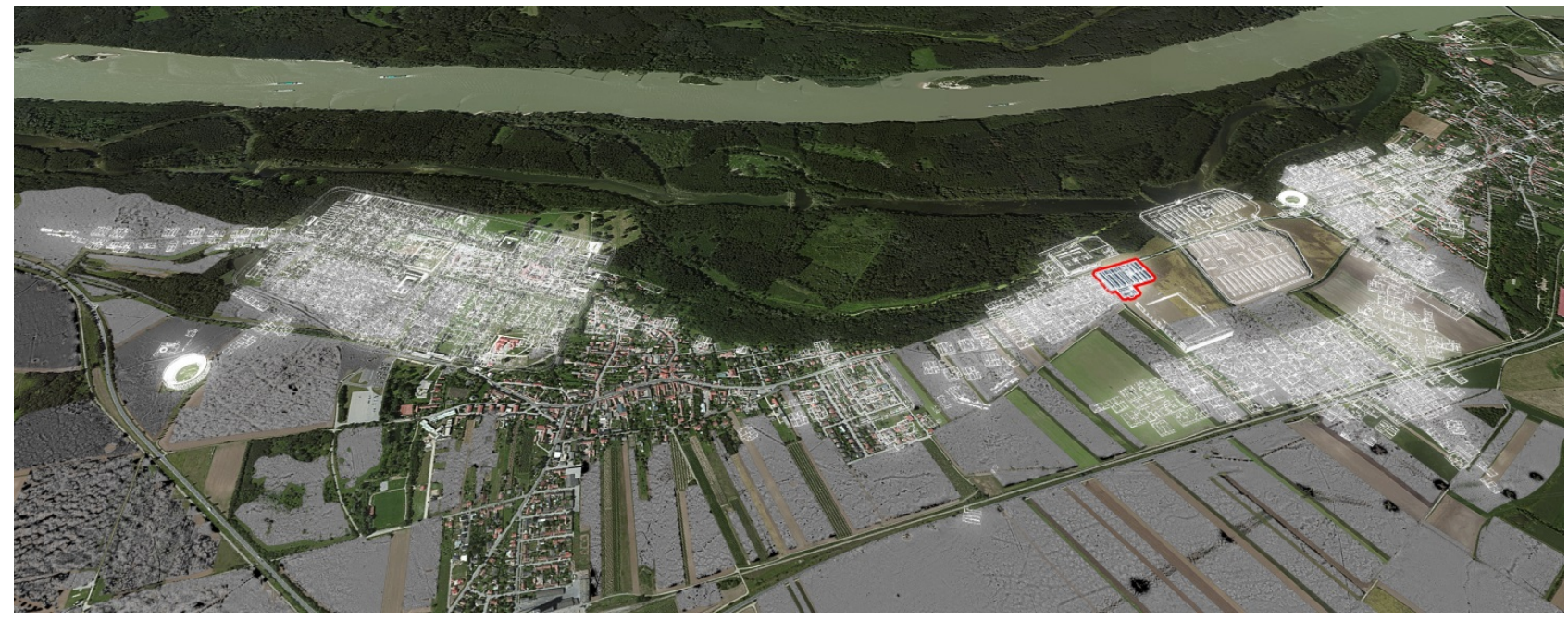

Figure 3: The Roman town of Carnuntum and its landscape.

The geospatial-temporal conclusions derived from the proposed approach are sufficient to understand the complexity of an archaeological landscape, to such an extent that destructive methods must not be applied beyond key-hole inspections.

Non-invasive archaeological investigations of entire landscapes have become possible by finding ways to deal with the large amount of acquired data, for the first time permitting the generation of a detailed bigger picture without the need to destroy cultural heritage.

\section{Acknowledgements}

The Ludwig Boltzmann Institute for Archaeological Prospection and Virtual Archaeology (archpro.lbg.ac.at) is based on an international cooperation of the Ludwig Boltzmann Gesellschaft $(A)$, the University of Vienna (A), the Vienna University of Technology (A), ZAMG - the Austrian Central Institute for Meteorology and Geodynamics (A), the Province of Lower Austria (A), Airborne Technologies (A), 7reasons (A), the Austrian Academy of Sciences (A), the Austrian Archaeological Institute (A), RGZM - the Roman-Germanic Central Museum in Mainz (D), the Swedish National History Museum (S), the University of Birmingham (GB), Vestfold County Council (N), and NIKU - the Norwegian Institute for Cultural Heritage Research (N).

\section{References}

ARROYO-BISHOP, D. and LANTADA ZARZOSA, M.T., 1995. To be or not to be: will and object-space-time GIS/AIS become a scientific reality or end up an archaeological entity? In Archaeology and geographical information systems: a European perspective, edited by G. Lock and Z. Stančič, London, pp. 43-53.

ASCHER, R., 1961. Experimental archaeology in: American Anthropologist, Menasha 63, 4, pp. 793-816.

ASPINALL, A. et al., 2008. Magnetometry for Archaeologists, AltaMira Press.

BECKER, H., 2009. Caesium-magnetometry for landscape archaeology. In: Campana S. and Piro S. (Eds.), Seeing the unseen - Geophysics and landscape archaeology, London, pp.129-165.

CARVER, G., 2004. Archaeological Information Systems (AIS): Adapting GIS to archaeological contexts, in Archäologie und Computer, Vienna.

CONYERS, L., 2004. Ground-Penetrating Radar for Archaeology, AltaMira Press.

DONEUS, M. and BRIESE, C., 2011. Airborne Laser Scanning in Forested Areas - Potential and Limitations of an Archaeological Prospection Technique. In: Cowley D. C. (ed.) 2011, Remote Sensing for Archaeological Heritage Management, proceedings of an EAC Symposium, Reykjavik, Iceland, 25 -27 March 2010, EAC Occasional Paper No. 5, Archaeolingua.

DONEUS, M. and NEUBAUER, W., 2005. Multiple survey techniques at Roman Carnuntum. Integrated prospection of the largest archaeological landscape in Austria. In: Chris Musson, Rog Palmer, Stefano Campana, In volo nel 
passato. Aerofotografia e cartografia archaeological. Biblioteca del dipartimento di archaeologia e storia delle arti sezione archaeologica, Siena, pp. 272-279.

DONEUS, M., 2013. Die hinterlassene Landschaft - Prospektion und Interpretation in der Landschaftsarchäologie, Mitteilungen der prähistorischen Kommission der ÖAW, Bd. 78, Wien.

DONEUS, M., DONEUS, N. and Neubauer, W., 2002. Integrated archaeological interpretation of combined prospection data, Zwingendorf (Austria) - a case study. In: R.H.Bewley, W. Raczkowski (Eds.) Aerial Archaeology, pp. 149-165.

DONEUS, M., GUGL, C. and DONEUS, N., 2013, Eine Modellstudie der Erforschung römischer Lagervorstädte, Von der Luftbildprospektion zur siedlungsarchäologischen Synthese. ÖAW (Der römische Limes in Österreich, Heft 47), Wien.

EDER-HINTERLEITNER et al, 2003. The city map of ancient Carnuntum - combining archaeological prospection, photogrammetry and GIS. Archaeologia Polona, 41, pp. 156-157.

GAFFENY C.F. and J. Gater, 2003. Revealing the buried past: geophysics for archaeologists. Tempus.

JOSEPH, N. et al., 2004. Replication in Archaeological Information Systems. In [Enter the Past] The E-way into the Four Dimensions of Cultural Heritage. CAA 2003. Computer Applications and Quantitative Methods in Archaeology; Proceedings of the 31st Conference, Vienna, Austria, April 2003, edited by Magistrat der Stadt Wien, Referat Kulturelles Erbe, and Stadtarchäologie Wien, Oxford, pp. 216-220.

KAREL, W. et al., 2013. Oriental - Automatic Geo-Referencing and Ortho-Rectification of Archaeological Aerial Photographs. In: P. Grussenmeyer (Hg.): TC V. XXIV International CIPA Symposium. Strasbourg, France, 02.06.09.2013 (ISPRS Annals, II-5/W1). Online verfügbar unter DOI: 10.5194/isprsannals-II-5-W1-175-2013.

KEAY, S. et al., 2009. The Role of Integrated Geophysical Survey Methods in the Assessment of Archaeological Landscapes: the Case of Portus. Archaeological Prospection 16, pp. 154-166.

KVAMME KI., 2007. Integrating Multiple Geophysical Datasets, 345-374 In: Remote Sensing in Archaeology, (Eds) Wiseman, J. And El-Baz, F., Springer.

KVAMME, KI., 2006. Integrating multidimensional geophysical data. Archaeological Prospection 13, pp. 57-72.

LANGRAN, G., 1992. Time in Geographic Information System, London.

LECKEBUSCH, J., 2003. Ground-penetrating Radar: A Modern Three-dimensional Prospection Method. Archaeological Prospection, 10, pp. 213-240.

LÖCKER et al., 2015. Successfully falsified ... On epimestological problems of archaeological excavations and geophysical surveys. In: Archaeological prospection: The Institute of Archaeology and Ethnology, Polish Academy of Sciences (Archaeologia Polona, 53), pp. 222-224.

LYATSKY H, 2004. The Meaning of Anomaly. CSEG Recorder, 29(6).

NEUBAUER, W. et al., 1999. Kombination archäologisch-geophysikalischer Prospektionsmethoden am Beispiel der römischen Zivilstadt Carnuntum. Archaeologia Austriaca Bd. 82/83, 1998/99, pp. 493-551 (17 ref.), 1-26.

NEUBAUER, W. et al., 2000. Kombinierte archäologische Prospektion am Beispiel der römischen Zivilstadt Carnuntum. Carnuntum Jahrbuch 2000, pp. 27-52.

NEUBAUER, W. et al., 2005. Large Scale GPR Surveys of Roman Buildings. Proceedings of the 33rd int. Symposium on Archeometry. Geoarchaeological and Bioarchaeological studies, vol. 3, pp. 23-30.

NEUBAUER, W. et al., 2012. Long-term Integrated Archaeological Prospection at the Roman Town of Carnuntum/Austria. In: P. Johnson und M. Millett (Hg.): Archaeological Survey and the City. Oxford: Oxbow (Monograph Series, No. 2), pp. 202-221.

NEUBAUER, W. et al., 2012. The Roman town of Carnuntum - an outstanding example of long-term integrated archaeological prospection. In: The Roman Archaeology Conference 22. Frankfurt am Main, Germany, 29.03 01.04.2012. Abstracts. Institutum Archeologicum Germanicum. Frankfurt am Main.

NEUBAUER, W. et al., 2014. The discovery of the school of gladiators at Carnuntum, Austria. In: Antiquity (88), pp. 173190.

NEUBAUER, W., 2001. Magnetische Prospektion in der Archäologie. Mitteilungen der prähistorischen Kommission der ÖAW, Bd. 44, Wien.

NEUBAUER, W., 2004. GIS in Archaeology - The Interface between Prospection and Excavation. Archaeological Prospection 11, pp. 159-166.

NEUBAUER, W., 2011. Archäologische Prospektion der Landschaft Carnuntum. In: Carnuntum und Limes. Denkmalpflege in Niederösterreich, Bd. 45, pp. 23-26.

SCHMIDT, A., 1996. Visualisation of multi-source archaeological geophysics data. Annales Geophysicae, 14, Suppl. I: C165. 
SCHMIDT, A., 2001. Visualisation of multi-source archaeological geophysics data. In M. Cucarzi and P. Conti (eds) Filtering, Optimisation and Modelling of Geophysical Data in Archaeological Prospecting, Rome: Fondazione Ing. Carlo M. Lerici, pp. 149-160.

SCOLLAR, I., TABBAGH, A., HESSE, A. and HERZOG, I., 1990. Archaeological Prospecting and Remote Sensing, Cambridge University Press.

TORREJÓN VALDELOMAR, J. et al., 2015. 4D investigation of Digital Heritage an interactive application for the auxiliary fortress of Carnuntum In: IEEE Conference Publications, 2015 Digital Heritage International Congress, Granada, Spain, 28.09-02.10.2015, Vol. 2, pp. 81-84. Online: DOI: 10.1109/DigitalHeritage.2015.7419457

TRINKS, I., JOHANSSON, B., GUSTAFSSON, J., EMILSSON, J., FRIBORG, J., GUSTAFSSON, C., and NISSEN, J., 2010. Efficient, large-scale archaeological prospection using a true 3D GPR array system. Archaeological Prospection, 17(3), 2010a. doi:10.1002/arp.381, pp. 175-186.

TRINKS, I., NEUBAUER, W. and DONEUS, M. 2012. Prospecting Archaeological Landscapes. In: loannides M. et al. (Eds.) EuroMed 2012, Progress in Cultural Heritage Preservation. Lecture Notes in Computer Science 7616, pp. 21-29.

WALLNER et al., 2015. Application of georeferenced Archaeological Information Systems for archaeological digital heritage - the auxiliary fortress of Carnuntum (Lower Austria). In: IEEE Conference Publications, 2015 Digital Heritage International Congress, Granada, Spain, 28.09-02.10.2015, Vol. 1, pp. 159-162. online: DOI: 10.1109/DigitalHeritage.2015.7413859

WALLNER et al., 2015. ArchPro Carnuntum Project Large-scale non-invasive archaeological prospection of the Roman town of Carnuntum. In: Archaeological prospection: The Institute of Archaeology and Ethnology, Polish Academy of Sciences (Archaeologia Polona, 53), pp. 400-403.

WHEATLEY, D. and GILLINGS, M. (ed.), 2002. Spatial Technology and Archaeology. The archaeological applications of GIS. London. 